\section{Aggressors and resilient youths in Medellin, Colombia: the need for a paradigm shift in order to overcome violence}

\author{
Agresores y resilientes en Medellín, Colombia: \\ necesidad de un cambio de paradigma para \\ superar la violencia
}

\author{
Agressores e resilientes em Medellín, Colômbia: \\ necessidade de uma mudança de paradigma, \\ a fim de superar a violência
}

Luis F. Duque †

Nilton E. Montoya 1

Alexandra Restrepo ${ }^{1}$

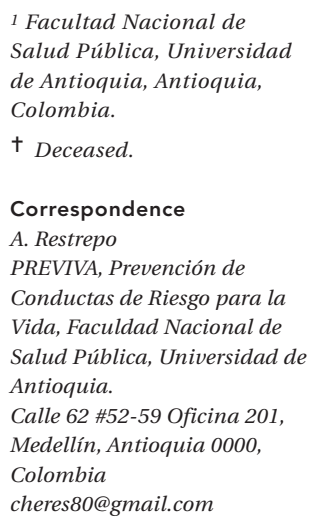

\begin{abstract}
The objective of this study was to estimate the ratio of resilient youth and compare this to youth with aggressive behavior, and to youth who also exhibit sexually risky behavior and drug use. A cross-section study of a representative sample of people between aged between 12 and 60 who are residents of Medellin, Colombia, and its metropolitan area $(N=4,654)$ was employed using probabilistic multi-stage sampling. Youth between 14 and 26 years old were selected for the present analysis $(n=1,780)$. The proportion of resilient youth is $22.9 \%$, of aggressors is $11.3 \%$, and that of youth with other risky conduct is $65.8 \%$. The high ratio of resilient youth calls for a reorientation of public policy toward prevention and control of violence, prioritizing the promotion of resilient behavior instead of continuing with tertiary prevention actions.
\end{abstract}

Violence; Agression; Health Promotion

\section{Resumen}

Los objetivos fueron estimar la proporción de jóvenes resilientes y comparar dicha proporción con la de jóvenes con conductas agresivas y con otras conductas de riesgo. Estudio transversal en una muestra representativa de personas entre los 12 a 60 años, habitantes de Medellín, Colombia, y el área metropolitana $(N=4.654)$. Muestreo probabilístico polietápico. Se seleccionaron los jóvenes entre 14-26 años para el presente análisis $(n=1.780)$. La proporción de jóvenes resilientes es de un 22,9\%, la de agresores un 11,3\%, la de jóvenes con otras conductas de riesgo es de un 65,8\%. La alta proporción de jóvenes resilientes obliga a reorientar las políticas públicas de la prevención terciaria y el control de la violencia a la promoción de las conductas resilientes y al desarrollo positivo de los niños y jóvenes en la sociedad.

Violencia; Agresión; Promoción de la Salud 


\section{Introduction}

Medellin, the second largest city in Colombia and situated in the northwest of the country, has a population of 2.3 million, of which $22 \%$ are youth (Departamento Nacional de Estadística. Estimación y proyección de población nacional, departamental y municipal por sexo, grupos quinquenales de edad y edades simples de 0 a 26 años 1985-2020. http://www.dane.gov.co/in dex.php?option=com_content\&view=article\&id $=75 \&$ Itemid=72, accessed on $20 / \mathrm{Feb} / 2012$ ). Half of these youth come from lower socioeconomic classes 1. Although in the period between 2002 and 2009, poverty and deprivation indicators in Medellin and the metropolitan area decreased (from $62 \%$ to $49 \%$ ), they still remain overwhelmingly high in comparison with the national level 2 and with other countries 3,4 . Despite this period being characterized by an important economic increase within the city, inequality, measured by the Gini coefficient, stayed approximately the same, shifting from 0.59 in 2002 to 0.58 in 2009 2. Medellin is one of the most unequal cities in Colombia.

Aggressors, as well as victims of interpersonal violence, including homicide, have mainly been young men 5,6. This causes more deaths than from other diseases, such as cardiovascular, infectious, and neoplasic ones 7 .

Since the 1980s, homicide has been one of the main causes of general mortality in the city. In 1976 , the proportion of general deaths that were homicides was $3.5 \%$, in 1985 it rose to $17 \%$, and in 1991 , it reached a peak of $41 \%$. From 1992, homicides started to decrease and in 1995, the figure was 30\%; between 1995 and 2002, the proportion of deaths due to homicide remained stable (a lost period), and in 2002, it was $28 \%{ }^{8}$. From 2002, the proportion of homicides started to decrease significantly, only to increase again from 2008 to 2010 9,10,11.

As a response to this situation, during the last 30 years, the Colombian state, and particularly the city of Medellin, has designed different policies to deal with problems of violence. In the last three decades, Medellin has passed through four stages of these policies to control violence:

a) The period leading up to 1992: the violence was mainly dealt with as a public order problem - therefore the policies created to reduce it were centered on activities of repression and punishment of aggressors and delinquents 12 . This attitude was strengthened by the evident growth and link of violent groups to narco-trafficking, a fact which became more visible from the 1980s onwards 8 . b) The period 1992-1999: beyond violence being solely a public order problem (often linked to narco-trafficking), it was perceived as being a problem that mainly affected youth and which had its origins in social and economic factors; different actions were embarked upon to re-socialize young aggressors, offering them job opportunities (albeit generally unstable and short-term), linking them to educational institutions, and encouraging participation in cultural activities and community development 13 . The principal demonstration of this was the action plan of Mayor of this period 14 and the creation of the Presidential Office of Antioquia (Consejería Presidencial para Antioquia), which strengthened reconciliation activities for youths in aggressor gangs, hoping for social reintegration 15. Various non-governmental organizations (NGOs) and the Archdiocesan Catholic Church of Medellin (Iglesia Arquidocesana de Medellin) supported this policy and promoted similar programs 16. The violence continued to be associated with the narco-trafficking business and the action of the government also continued to be of crime repression 12 .

c) The period 1999-2007: Proantioquia (J. M. Aristizabal) and the Corona Foundation (Fundación Corona) (G. Gutierrez) promoted the program Among Everyone (EntreTodos), with whose support international experts presented the etiological perspective of the violence in Medellin and proposed that violence is preventable, particularly early-on 17. The mayor's office of this period started formulating a far-reaching municipal program of prevention and violence regulation that was financed by the first loan that the municipality received in all its history from a multilateral bank, the Inter-American Development Bank. One of the components was the Medellin Early Prevention of Aggression Program (MEPAP), oriented towards the prevention of aggression and criminality in pre-schools and schools $18,19,20$, and though it has been successful 21, it has not been continued by subsequent municipal administrations. Currently, there were young aggressor re-socialization programs 22,23 and started re-socialization programs for members of illegal armed groups (guerillas and paramilitaries).

d) The period from 2007: in 2007, Metropolitan Agreement 33 was unanimously approved, which concerns the promotion of coexistence and the prevention of violence and related behaviors; this agreement covers Medellin and other municipalities of the metropolitan area (2007-2015). This agreement includes as a public policy for the first time, a regulation that obligates the implementation of a program to 
promote resilience in dealing with socially unacceptable behaviors as well as aggression (2007) 4,24 . Unfortunately this policy, although binding and obligatory, has not been implemented in a strong way for the municipalities of the Medellin metropolitan area.

However, the public policies of Medellin have included elements that are part of the spirit of the metropolitan agreement, for example widening coverage of education, which can be seen in the development plan of 2008-2011 that proposes the maintenance and consolidation of a climate of good citizenship 25. Up until recently, a policy and a program that promote resilient behavior and play a priority role in municipal policy have yet to be formulated and implemented. In reality, an important part of the municipality of Medellin's budget is dedicated to the re-socialization of young aggressors. Regardless of these efforts focused on the regulation and control of violence, the feeling of insecurity, and the rates of different forms of violence have increased in the city in the last four years 26 .

To tackle the phenomenon of violence, the concepts of resilience and health promotion have been proposed in the last few decades by authors such as Bronffrenbrener 27, Benson 28, and Balsano et al. 29. The concept that Ungar puts forward is that resilience is dynamic - it is a process and not a state. It is a process molded by culture, where the following factors intervene: making a decision about personal development; what the young person makes of the goods, services, and formal and informal opportunities that are in their reach; and the availability of these 30

There are youth that have been exposed to risk factors and adverse situations in society, like social exclusion, socioeconomic deprivation, exclusion based on gender, age, ethnic group, social or economic status; or who have lived through stressful familial or environmental situations; but these youth overcome these challenges without exhibiting risky or socially-unacceptable behaviors. We consider these youth to be "resilient". They achieve not only their own personal development, but also sometimes give support to others or promote development in their community 30,31 .

This article attempts to describe the extent of resilience in relation to severe aggression in youth in Medellin.

\section{Methodology}

For this analysis, was used the database from a population survey of Medellin and its metro- politan area carried out in 2007 was utilized 5 . It was a cross-sectional study to determine the prevalence of different forms of violence and risky behaviors, as well as factors associated with violence, coexistence, and other risky behaviors.

The target population of the survey was people from 12 to 60 years of age from the urban zone. In Medellin, 2,095 people were surveyed; in each of the nine remaining municipalities, approximately 300 people were surveyed each with a total of 2,559 surveys done in these areas. The response rate was $93 \%$. An optimal allocation was made based on results in a similar study from 2004.

For this analysis we used the youth population sample ( $\mathrm{n}=1,780)$, of 12 to 26 years of age, in accordance with the Colombian legal definition of youth 32

Probabilistic, multi-stage sampling was employed, using stratification variation according to the complexity of the municipality 5 .

The same instrument from the PREVIVA program's (Life Risk Behaviors Prevention Program: an institucionalized program of the National School of Public Health, University of Antioquia, for research on prevention of risky behaviors for health) 2004 survey was used 4,33.

Quality control in the field was carried out, and $10 \%$ systematic random sample was taken to verify by telephone survey performance. Besides this, quality control was done for $10 \%$ of digitalized surveys. To see more details about the methodology of this study, other publications can be consulted 5,34 .

\section{Criteria of inclusion and exclusion}

For the purpose of this analysis, the following factors of inclusion and exclusion were taken into account for resilient youth, young aggressors, and adolescents with other risky behaviors and risk and aggression factors: (1) a resilient youth is someone who has been exposed to risk or stress factors without becoming a severe aggressor or having presented any of the other risky behaviors considered in this analysis; (2) a severe aggressor is someone who has presented one of the aggressive behaviors, independent of whether or not they have had risk factors or shown other risky behaviors; (3) there are adolescents with other risky behaviors, but who have not been aggressors, independent of whether or not they have been exposed to stressors.

The risk factors and stressors that have been taken into account are:

- If they have suffered from an illness or serious accident in the last year;

- If a member of the family that is responsible 
for covering family expenses has lost their job in the last year;

- If there has been a significant decrease in the family income in the last year;

- If there has been a lack of money for food in the last year;

- If they have been the victim of forced displacement in their life;

- If they have been the victim of attempted sexual abuse in their life;

- If they have been the victim of extortion in the last year;

- If they have been the victim of an attack by a firearm or sharp object in their life;

- If they have been the victim of a kidnapping in the last year;

- If their father, mother, sibling or uncle/aunt has participated in narco-trafficking;

- If their father, mother, sibling or uncle/aunt has participated in a robbery;

- If their father, mother, sibling or uncle/aunt has been a prisoner or detained by the police;

- If they have been the victim of physical aggression with an object by their father or mother during childhood;

- If they have been the victim of physical aggression that caused an injury by their father or mother during childhood;

- If they have been the victim of physical aggression with an object during childhood or adolescence by a relative;

- If they have been the victim of physical aggression without an object during childhood or adolescence by a relative;

- If they have been the victim of physical aggression that caused an injury during childhood or adolescence by a relative;

- If they have been the victim of a threat by a blade-style weapon during childhood or adolescence by a relative;

- If they have been the victim of a knife attack or other sharp weapon during childhood or adolescence by a relative;

- If they have been burned during childhood or adolescence by a relative;

- If they have been the victim of a threat from a firearm during childhood or adolescence by a relative;

- If they have been the victim of aggression from a firearm by a relative;

- If they have been the victim of being thrown out of their house during childhood or adolescence;

- If they have been the victim of attempted sexual abuse during childhood or adolescence by a relative;

- If they have been the victim of rape during childhood or adolescence by a relative;
- If they have been the victim of threats that obliged them to move from their home during childhood or adolescence;

- If they have been the victim of an attack with a sharp object in their neighborhood;

- If they have been the victim of a threat from a firearm in their neighborhood;

- If they have been the victim of aggression from a firearm in their neighborhood;

- If they have been the victim of attempted sexual abuse in their neighborhood;

- If they have been the victim of sexual abuse in their neighborhood.

The severe aggressions considered are:

- Having demanded from or threatened someone for money in their life;

- Having threatened someone with a firearm or sharp object in their life;

- Having threatened someone to move from their home in their life;

- Having attacked someone with a firearm or sharp object in their life;

- Having robbed someone at gunpoint in their life;

- If they have caressed another person without their consent on their genitals, breasts, legs or buttocks in their life;

- If they have attempted to rape or raped someone in their life;

- If they have killed someone in their life.

The other risky behaviors considered for this analysis are:

- If they have consumed any of the following psychoactive drugs ever in their life: heroin, morphine, cocaine, marijuana, mushrooms or LSD;

- If they have not used a condom in the last six months during sexual relations;

- If they have had three or more sexual partners in the last year.

\section{Analysis}

Percentage distribution, prevalence ratio out of 100 , and its $95 \%$ confidence interval $(95 \% \mathrm{CI})$ were calculated and the number of people with each characteristic was estimated for the metropolitan area of Medellin.

Given that the definition of a resilient youth assumes that they were youth exposed to risk factors but that they did not develop severe aggressive conduct, it was necessary to find a technique that allowed us to determine how many risk factors to take into consideration when classifying a resilient youth. For this, a ROC curve was calculated that permitted the inclusion of the number of risk factors and stressors that would better predict whether the youth would be a severe aggressor or be resilient. 


\section{Results}

The largest number of youth in each of the three groups considered have three or more stressors; there were no youth with nine or more stressors in any of the three groups (Table 1). When calculating the ROC curve, the findings predicted that with three risk factors, there is a sensitivity of $85 \%$ being aggressors.
For the purpose of this study, a resilient youth is one that has experienced three or more risk factors but has not presented any of the severe aggressive behaviors or any of the other risky behaviors at the time of the study.

Table 2 presents demographic characteristics of youth in Medellin and its metropolitan area. The first thing that strikes one's attention is that the aggressors are approximately $10 \%$ of

Table 1

Percentage distribution of resilient, severe aggressors, and youths with other risky behavior, according to number of risk factors. Medellin, Colombia.

\begin{tabular}{|c|c|c|c|}
\hline \multirow[t]{2}{*}{ Number of risk factors } & \multicolumn{3}{|c|}{ Study group } \\
\hline & $\begin{array}{l}\text { Resilient } \\
\text { youths }\end{array}$ & $\begin{array}{c}\text { Severe aggressor } \\
\text { youths }\end{array}$ & $\begin{array}{c}\text { Youths with other } \\
\text { risky behavior }\end{array}$ \\
\hline 0 & 0.0 * & 1.5 & 18.1 \\
\hline 1 & 0.0 * & 6.9 & 19.2 \\
\hline 2 & 0.0 * & 6.4 & 20.5 \\
\hline 3 & 37.1 & 15.8 & 12.5 \\
\hline 4 & 24.6 & 16.3 & 10.9 \\
\hline 5 & 18.9 & 12.9 & 6.8 \\
\hline 6 & 9.6 & 11.4 & 4.8 \\
\hline 7 & 6.4 & 9.4 & 2.4 \\
\hline 8 & 1.7 & 7.4 & 1.9 \\
\hline 9 & 1.2 & 4.0 & 1.5 \\
\hline
\end{tabular}

* According to the ROC curve results, an individual was considered resilient when he or she reported three or more risky behaviors.

Table 2

Prevalence per 100 (95\% confidence interval - 95\% Cl) of resilient youth, severe aggressors and youth with other risky behaviors. Medellin, Colombia.

\begin{tabular}{|c|c|c|c|}
\hline \multirow[t]{4}{*}{ Variable } & \multicolumn{3}{|c|}{ Study groups } \\
\hline & Resilient & Severe aggressor & Youths with other \\
\hline & youths & youths & risky behavior \\
\hline & $\%(95 \% \mathrm{Cl})$ & $\%(95 \% \mathrm{Cl})$ & $\%(95 \% \mathrm{Cl})$ \\
\hline \multicolumn{4}{|l|}{ Gender } \\
\hline Masculine & $22.8(20.0-25.7)$ & $17.3(14.8-19.9)$ & $60.0(56.7-63.2)$ \\
\hline Feminine & $23.0(20.2-25.9)$ & $5.4(4.0-7.1)$ & $71.6(68.5-74.6)$ \\
\hline \multicolumn{4}{|c|}{ Socioeconomic stratum } \\
\hline Low & $25.4(22.7-28.3)$ & $13.4(11.3-15.8)$ & $61.2(58.0-64.3)$ \\
\hline Medium & $20.6(17.7-23.8)$ & $9.4(7.3-11.7)$ & $70.0(66.5-73.3)$ \\
\hline High & $15.0(8.6-23.5)$ & $6.0(2.2-12.6)$ & $79.0(69.7-86.5)$ \\
\hline \multicolumn{4}{|l|}{ Total } \\
\hline Total & $22.9(20.9-24.9)$ & $11.3(9.9-12.9)$ & $65.8(63.5-68.0)$ \\
\hline $\mathrm{N}$ & 407 & 202 & 1,171 \\
\hline
\end{tabular}


the youth population, or about 100,000 in the metropolitan area of Medellin, while the resilient youth are about one quarter $(n=200,756)$; in other words, there are two resilient youth for every severe aggressor. The rest, who are neither resilient nor aggressor, but that exhibit sexually risky behavior or the use of psycho-active drugs increase to be almost two thirds of youth, or about 578,000 . Five youths could not be classified in any of the three groups of the study and so were excluded from the analysis.

The ratio of resilient youth is similar according to gender, but that of the aggressors is two times more among males than among females. Although there is a tendency to be more resilient in higher socio-economic classes, the observed differences are not of statistical significance.

\section{Discussion}

In Colombia, not many studies have been done on resilience. It is important to highlight the study by Klevens \& Roca 356 who studied perceptions of violence and aggression of different groups of youth in convenience samples. The ones considered to be resilient were those that did not commit crimes, did not rob, did not run away from home or drop out of school, but that were exposed to risk factors. Forty-four percent were exposed to one stressor, $38 \%$ to two stressors, and $18 \%$ to three or more risk factors (abandonment or separation of parents, intra-family violence, socio-economic difficulties).

Duque et al. 36 published a study comparing severe aggressors, paramilitaries, aggressors who fight, resilient youth, as well as a control group; the study found that resilient youth had a high ratio of two-parent households, and had a high ratio of having a mother that watched them and with whom they could have good and close communication.

Regardless of the fact that there is a higher number of resilient youth in relation to aggressors, youth programs are still oriented towards mainly controling cases of non socially acceptable risky behaviors (drug use, adolescent pregnancy, aggression, criminality), as well as penalizing offenders and creating incentives for their re-socialization. Actions have mainly focused on coercive regulation of youth or endeavoring to disband gangs and stop their delinquent activities.

To sum up, municipality and society have spent thirty years focused on tertiary prevention, basically working on the effects and manifestations of violence, and not on preventing its occurrence. Forty years ago, Leavell \& Clark 37 proposed three stages for the understanding of prevention of illness: a continuum that is initiated with primary prevention, or in other words, that prevents a pathology starting; continuing with secondary prevention that prevents the development of the illness after effective contact between agent and host, or when the nosologic continuum has been initiated; and finally culminates with tertiary prevention which focused on preventing complications, disability, and the death of a patient that presents specific symptoms of a pathology.

The concept of health promotion proposed in the Ottawa Charter of 1986 is very broad, it sets out to "provide the means necessary for people to improve their health and exercise more control over it" 38. In other words, health is presented as a positive concept that is supported by social resources, as well as by the physical and psychological capacities of people.

Health promotion has among other purposes, to initiate processes of social change, seeking the improvement of life conditions for people towards healthier living, like peace, housing, education, income, social justice, and equality. This focus requires therapeutic and preventative paradigms to change into a socio-ecological paradigm, where it deals with injustices, social justice, and social norms. It would move from an individual focus to a collective one 38 .

The notion of resilience and the fact that in Medellin and its metropolitan area the amount of resilient youth to that of aggressor youth is double, invites a re-evaluation of the very base of a policy promoting coexistence and prevention of violence, where youth are not viewed as being merely a problem that needs to be solved, but rather the source of a solution to the problems of this sick society.

Regardless of these conceptual developments, the city's public policy continues to be mainly focused on tertiary prevention, which attacks only the expressions and consequences of violence, without focusing on its prevention and promoting coexistence. We believe that a paradigm change is necessary: health promotion, coexistence, and work with resilient youth populations should be the center and focus of attention, albeit not being the only public policy.

Encouraging resilience and health promotion in adolescents and youth, and hopefully from early childhood, is to give them an important qualitative start in the orientation of the city. It is meaningful to change the focus of efforts from offsetting a dangerous situation for society (violence and criminality) and to prevent its occurrence, to promote change toward a positive society, based in the important number of resilient youth there are in the city. 
Support programs for resilient youth have been proposed to be of a community nature stimulating communities to promote their potential; Benson 28 recommends 40 elements that should be taken into consideration when forming this type of community.

Implementing such community programs is much more complex, consumes more time, and is more difficult than focusing attention on youth with more probability of being resilient. For this, we suggest working with groups of adolescents and youth among whom there is a good number that have a higher probability of being resilient; this can be detected by using a screening process. We have validated a screening test in Medellin for resilient youth, the CYRM Colombia 39 that could be used for this purpose. The Center for Health Communication at Harvard University has identified 10 tasks that could strengthen resilience among youth and five basic elements for family up-bringing with this same purpose 40 .

The 10 tasks proposed to strengthen resilience in youth are: (1) make adjustments to their own bodies and sexually mature feelings; (2) develop and apply abstract thought; (3) develop and apply a complex level of perspective; (4) develop and apply new skills in decision-making, resolution of problems, and conflict resolution; (5) identify moral standards, values, and significant beliefs; (6) understand and express complex emotional experiences; (7) construct friendships that are mutually close and supportive; (8) establish crucial identity aspects, (9) fulfill the appropriate demands of roles and responsibilities with growing maturity; and (10) re-negotiate relations with adults in reference to fatherhood and motherhood roles 40 .

The five basic elements that promote resilience in the up-bringing of youth in families are: (1) affection and communication; (2) supervision of behavior and well-being of the child; (3) offering guidance and setting limits; (4) establishing models and giving advice; and (5) providing and finding resources for personal growth, including other adults 40 .
What can a poor country like Colombia and a highly unequal society like Medellin offer resilient adolescents and youth?

First, the leaders of society (public, private and community) need to be convinced that a society that builds its future on resilience promotion is stronger and more vigorous economically, and socially more developed than one that perpetuates a model that privileges offsetting expressions and the effects of violence. It is probable that this change will not be easy because it implies the growth of a new point of view of people and society.

Second, actions that have confirmed efficacy, that improve education practices, upbringing in the family and prevent child abuse in the family, as well as actions that promote informal vigilance by the members of the community within the neighborhood and promote its social cohesion are all necessary. These elements have been identified as the main protective factors of violence in Medellin and its metropolitan area 4,41.

As a third element, it is necessary to consider the promotion of equity in opportunities, given that an important background element in the generation of violence in the city is social inequality ${ }^{4,41}$.

Besides working with resilient populations, the city's public policy should continue with strengthening programs and projects for aggressor populations and those that have been "rehabilitated" into society, but taking into consideration that the rate of relapse is close to $15 \% 42$, which highlights the fact that these programs cannot be considered the only focus in overcoming violence; instead it should also strengthen prevention of risky behavior in early childhood (0 to 5 years old), pre-school and school ages (5 to 11 years old), as well as continue with an efficient crime repression policy.

To evaluate the efficacy attributable to these programs, to document successful experiences, and to recognize lessons that increase the knowledge base about this phenomenon in the city are tasks, above all else, for academics, that should focus on improving their knowledge of the reality and the formulation of responses to these problems. 


\section{Resumo}

Os objetivos foram estimar a proporção de jovens resistentes e compará-la com jovens com condutas agressivas, e jovens que também apresentam comportamento sexual de risco e uso de drogas. Estudo transversal de uma amostra representativa de pessoas com idades entre 12 e 60 anos, habitantes de Medellín e sua área metropolitana, na Colômbia $(N=4.654)$, foi utilizado a partir de amostragem probabilística multiestágio. Jovens entre 14 e 26 anos foram selecionados para a presente análise $(n=1.780)$. A proporção de jovens resistentes foi de 22,9\%, de agressores 11,3\%, e de jovens com conduta de risco foi de 65,8\%. A alta proporção de jovens resistentes força uma reorientação das políticas públicas para a prevenção e controle da violência, privilegiando a promoção de condutas de resistência ao invés de continuar com ações de prevenção terciária.

Violência; Agressão; Promoção da Saúde

\section{Contributors}

L. F. Duque participated in the article conception, data analysis and write-up. N. E. Montoya collaborated with the data processing, database design and write-up. A. Restrepo participated in the data analysis, revision of content and support in the write-up.

\section{Acknowledgments}

The authors would like to thank David Hernández for his support in the bibliographical search. This article is based on a research project financed by the Research Committee (Comité de Investigaciones - CODI) of the University of Antioquia (project: Características y Uso de los Recursos Institucionales y Familiares de Jóvenes Resilientes de Medellín. Un Estudio de Casos y Controles. INV297-09), and on CODI's sustainability program of successful research groups 2011-2012.

\section{Conflicts of interest}

The authors declare that there are no conflicts of interest in the publication of this article.

\section{References}

1. Grisales H. Línea de base del indice de desarrollo juvenil, 2011. Medellín: Metrojuventud; 2012.

2. Observatorio de Políticas Públicas de la Alcaldía de Medellín. Medellín en cifras. Medellín: Observatorio de Políticas Públicas de la Alcaldía de Medellín; 2011.

3. United Nations Development Program. Patterns and trends in human development, equity and environmental indicators. In: United Nations Development Program, editor. Human development report 2011. New York: United Nations Development Program; 2012. p. 25-48.

4. Duque LF. La violencia en el Valle de Aburrá: caminos para la superación. Medellín: Cátedra Litográfica; 2007.

5. Duque LF, Montoya NE, Restrepo A. Violence witnessing, perpetrating and victimization in Medellin, Colombia: a random population survey. BMC Public Health 2011; 11:628.

6. Bonilla L. Demografía, juventud y homicidios en Colombia. 1979-2006. Cartagena: Banco de la República; 2009.

7. Londoño JL, Grisales H, Fernández SY, Cardenas E. Años de vida saludables perdidos por la población de Medellín. Un análisis especial por homicidio y accidentes de vehículo motor. Rev Fac Nac Salud Pública 1999; 17:63-92.
8. Carmona M, García HI, Giraldo CA, López MV, Suárez CM, Corcho DC, et al. Escenarios de homicidios en Medellín (Colombia) entre 1990-2002. Rev Cubana Salud Pública 2005; 31:202-10.

9. Álvarez Acero AP. Homicidios 2009. Aproximaciones a los conceptos de feminicidio y homicidio en mujeres: bases para su medición. Bogotá: Instituto Nacional de Medicina Legal y Ciencias Forenses; 2010.

10. Álvarez Acero AP. Descripción del comportamiento del homicidio en Colombia. Bogotá: Instituto Nacional de Medicina Legal y Ciencias Forenses; 2011.

11. De La Hoz-Bohórquez GA, Vélez-Rodríguez MC Homicidio: Colombia 2008. Bogotá: Instituto Nacional de Medicina Legal y Ciencias Forenses; 2009.

12. Ceballos R. Violencia reciente en Medellín, una aproximación a los actores. Bulletin de l'Institut Francais d'Études Andines 2000; 29:381-401.

13. Castro MF, Ferro MS. La respuesta a la criminalidad y la violencia en Colombia: acciones del Estado para promover la convivencia y la seguridad en las ciudades. http://www.fuac.edu.co/download/ AREAS/7vc.pdf (accessed on 20/Feb/2012). 
14. Alcaldía de Medellín. Plan estratégico de seguridad para Medellín y su área metropolitana. Medellín: Alcaldía de Medellín; 1994.

15. Consejería Presidencial para Medellín y su Área Metropolitana. Medellín: alternativas de futuro. Medellín: Consejería Presidencial para Medellin y su Área Metropolitana; 1992.

16. Alcaldía de Medellín. Política de seguridad y convivencia ciudadana para Medellín: estado del arte. Medellín: Alcaldía de Medellín; 2001.

17. Duque LF. Programa de convivencia ciudadana: antecedentes y evolución del programa de convivencia ciudadana de Medellín. Medellín: Alcaldía de Medellin; 2000.

18. Klevens J, Montoya E. Un abordaje de la violencia desde la salud pública: el proyecto de prevención temprana en Medellin. Rev Salud Pública 2003; 5:24-39.

19. Duque LF, Klevens J, Ungar M, Lee AW. Violence prevention program in Colombia: challenges in project design and fidelity. In: Ungar M, editor. Handbook for working with children and youth: pathways to resilience across the cultures and context. Thousand Oaks: SAGE Publications; 2005. p. 455-71.

20. Duque LF, Ungar M, Caicedo B. Addressing youth violence and aggression in Colombia: Examining a community-wide prevention initiative. In: Denov M, MacLure R, Campbell K, editors. Children's rights and international development lessons and challenges from the field. New York: Palgrave Macmillan; 2011. p. 129-54.

21. Duque LF, Orduz JF, Sandoval JJ, Caicedo BE, Klevens J. Lecciones del programa de prevención temprana de la violencia, Medellín, Colombia. Rev Panam Salud Pública 2007; 21:21-9.

22. Alcaldía de Medellín. Plan de Desarrollo de Medellín 1998-2000. Por una ciudad más humana. Medellín: Alcaldía de Medellin; 1998.

23. Alcaldía de Medellín. Plan de desarrollo de Medellín 2001-2003: Medellín competitiva. Medellín: Alcaldía de Medellín; 2001.

24. Universidad de Antioquia. Politica pública para la promoción de la convivencia y la prevención de la violencia en el Valle de Aburrá. 2007-20015. Medellín: Universidad de Antioquia; 2007.

25. Alcaldía de Medellín. Plan de gobierno 2008-2011. Medellín: Alcaldía de Medellín; 2008.

26. Alcaldía de Medellín Medellin cómo vamos: encuesta de percepción ciudadana. Medellín: Alcaldía de Medellín; 2011.

27. Bronfenbrenner U. The ecology of human development. Cambridge: Harvard University Press; 1979.

28. Lerner RM, Benson PL. Developmental assets and asset-building communities: implications for research, policy, and practice. New York: Kluwer Academics; 2003.

29. Balsano AB, Phelps E, Theokas C, Lerner JV, Lerner RM. Patterns of early adolescents' participation in youth development programs having positive youth development goals. J Res Adolesc 2009; 19:249-59.
30. Ungar M. Resilience across cultures and contexts. In: Ungar M, editor. Handbook for working with children and youth: pathways to resilience across cultures and contexts. Thousand Oaks: SAGE Publications; 2005. p. 15-9.

31. Kaplan HB. Toward an understanding of resilience: a critical review to definitions and models. In: Glantz MD, Johnson JL, editors. Resilience and development positive life adaptations. New York: Kluwer Academic/Plenum Publishers; 1999. p. 17-83.

32. Presidencia de la República de Colombia. Política Nacional de Juventud: bases para el Plan Decenal de Juventud 2005-2015. http://planipolis.iiep. unesco.org/upload/Youth/Colombia/Colombia Politica_nacional_juventud.pdf (accedido el 20/ Feb/2012).

33. Duque LF. La violencia en el Valle de Aburrá: su magnitud y programa para reducirla. Medellín: Fotográficas Mario Salazar; 2005.

34. Duque LF, Montoya N, Restrepo A. Violencia, alcohol, drogas, tabaco y sexualidad insegura en Medellín y el Área Metropolitana. Medellín: Facultad Nacional de Salud Pública; 2011.

35. Klevens J, Roca J. Nonviolent youth in a violente society: resilience and vulnerability in the country of Colombia. Violence Vict 1999; 14:311-22.

36. Duque LF, Klevens J, Montoya NE. Conductas socialmente indeseables asociadas a agresores y resilientes: un estudio de casos y controles en Medellín, Colombia, 2003-2005. Rev Fac Nac Salud Pública 2007; 25:21-36.

37. Leavell HR, Clark EG. Preventive medicine for the doctor in his community. 2nd Ed. New York: McGraw Hill; 1958.

38. Asociación Médica Mundial. Carta de Ottawa para la promoción de la salud. Primera Conferencia Internacional sobre la Promoción de la Salud. Ottawa: Asociación Médica Mundial; 1986.

39. Montoya NE, Restrepo A, Duque LF, Ungar M. Predicting resilient adolescents and youths: validation of screening test in Colombia. Issues Compr Pediatr Nurs 2011; 34:167-88.

40. Rae Simpson A, Roehlkepartain JL. Asset build in parenting practices and family life. In: Lerner RM, Benson PL, editors. Develomental assets and assets-build communities. New York: Kluwer Academics; 2003. p. 157-94.

41. Duque LF, Restrepo A, Montoya NE. Violencia interpersonal en Colombia. In: Arbeláez MP, Molina G, editors. Analisis de situación de salud de Colombia. Bogotá: Ministerio de la Protección Social; 2011. p. 81-117.

42. Massé F, Nussio E, Negrete V, Ugarriza JE. Tomo II. Área de desarme, desmovilizaciòn y reintegración. In: Cuarto Informe del Observatorio Internacional de Desarme, Desmovilización y Reintegración Ley de Justicia y Paz. Madrid: Observatorio Internacional de Desarme, Desmovilizaciòn y Reintegración; 2011. p. 5.

Submitted on 16/Dec/2012

Final versión resubmitted on 26/Apr/2013

Approved on 08/May/2013 